\title{
ANALYSIS OF PROTEIN IN WHEAT GRAIN
}

\author{
Venkata Naga Kaumudi Prabha Annavarapu ${ }^{1} 凹$, Murali Krishna Pamarthi $2 \square$ \\ ${ }^{1}$ Teesside University, Middlesborough, United Kingdom.
}

Received 1 September 2021

Accepted 15 September2021

Published 30 September2021

\section{CorrespondingAuthor}

Venkata Naga Kaumudi Prabha

Annavarapu,

kaumudiprabha1996@gmail.com

\section{DOI}

10.29121/granthaalayah.v9.i9.2021. 4286

Funding: This research received no specific grant from any funding agency in the public, commercial, or not-for-profit sectors.

Copyright: (C) 2021 The Author(s). This is an open access article distributed under the terms of the Creative Commons Attribution License, which permits unrestricted use, distribution, and reproduction in any medium, provided the original author and source are credited.

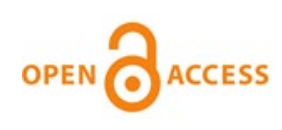

\section{ABSTRACT}

Wheat is one of the most important cereal crops grown with highest demand. Nitrogen content that enables the protein in the grain is necessary for baking and processing quality. The importance of wheat protein and its functionality in bakery products are well discussed in the given topic. This Study was carried out to study the effect of nitrogen fertilizer supply and its implications on bread wheat variety in the baking process. Dumas's method is used for estimating the protein content in the bread variety that is grown in two different nitrogen fertilizers supply with $100 \mathrm{~kg} / \mathrm{ha}$ and $350 \mathrm{~kg} / \mathrm{ha}$ respectively. The results clearly depict the highest growth of bread wheat variety which was grown in $350 \mathrm{~kg} / \mathrm{ha}$ of nitrogen supply has high amount of protein content. Wheat is the best source of carbohydrates and the proteins present in are gliadin and glutenin which are responsible to provide viscoelastic properties in the bakery products. Functionality of the bakery products are well discussed in the introduction part. The result includes test values and graphs have been plotted based on the comparison of protein present in bread. In the discussion section the differences and effects of protein in processing of foods are analysed against similar other research works.

Keywords: Wheat Proteins, Dumas Method, Viscoelasticity Properties, Nitrogen Fertilizers

\section{INTRODUCTION}

Wheat (Triticum aestivum) is the fourth most staple crop consumed by world's population occupying 22\% cultivated area Shewry (2009). Wheat cultivation has been started around $8500 \mathrm{BC}$ in Greece later reaching India and Cyprus in 6500BC, Egyptians are the first developers of the usage of oven and baking products into large food scale industries Brennan (2009). The wheat crop has three major phases which considers the demands of nitrogen (Figure 1). For wheat crops to obtain proper yields good amount of nitrogen fertilizer $(60 \mathrm{~kg} \mathrm{~N}$ ha-1) must be used additionally added Zadoks et al. (1974). Wheat crop contains $6 \mathrm{mg}$ of proteins in the kernel for the sufficient growth of the leaves (Figure 1). In the second stage nitrogen content is responsible for the growth of the tillers per plant Bogard et al. (2010). In the third stage the aim of the nitrogen is to build up the protein in the wheat grain Pechanek et al. (1997). In the modern day the percentage of the protein in the grain should be $12 \%$ dry matter; amino acids content must be high in vegetative tissues and are transported to newly forming grain where storage proteins are developed (Figure 1). The process is influenced by late application of nitrogen content where the activity of roots is declined. Hence if nitrogen content was decreased the plant cannot build up protein during the development of kernels. 
Yu et al. (2017). However, single application of nitrogen showed same protein in the recent trials in southern Germany Schulz et al. (2015). Flag leaves are important for developing nitrogen metabolites which forms amino acids that are transported to kernels Barneix and Guitman (1993). However, it is not sufficient to reach the protein content; due to high temperatures, the nitrogen content will be decreased. Hence the protein in organic farming shows lower percentage (40\%) compared to conventional agricultural systems Hellemans et al. (2018). Therefore, protein concentration will be varied even same genotype of wheat is used Zörb et al. (2006).

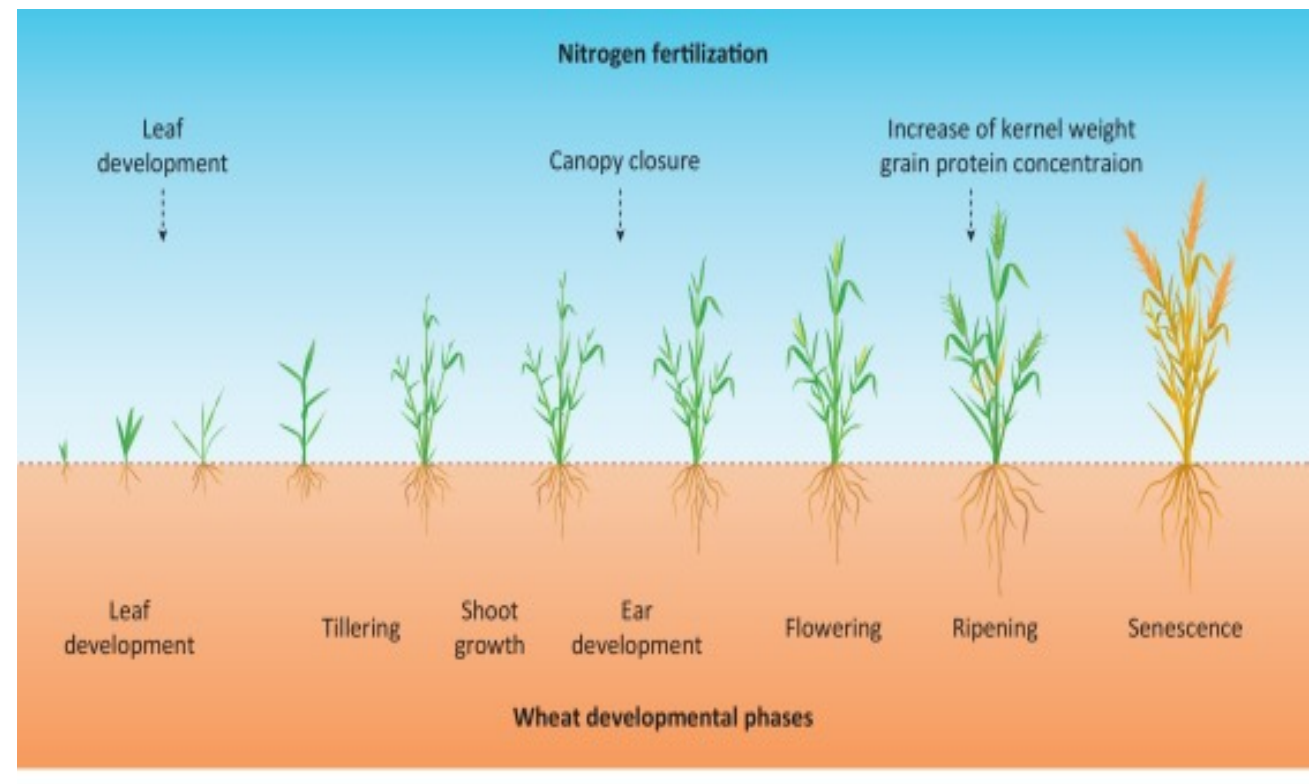

Trends in Plant Science

Figure 1 Development phase of wheat showing increased protein concentration in kernel Zörb et al. (2018)

Singh et al. (2016). However, grain quality can also be increased by increasing the storage proteins in modern varieties. In 1960 , Germany has showed a high protein $(12 \%$ to $16 \%)$ content by using improved nitrogen fertilization Laidig et al. (2016). Hence if farmers decided to make bread, he or she will use different varieties of nitrogen applications for obtaining high protein Munier and Salon (2005).

Transriptome studies showed that 30,000 genes are present in developing wheat grain Wan et al. (2008). However, there is no influence of these components on the protein content of the wheat grain. Prolamin storage proteins that are related to gluten proteins have high impact on bread making (Figure 2) Shewry (2009). It is estimated to account $80 \%$ of protein in wheat grain of European wheat's Seilmeier et al. (1991). According to Osborne in 1907 the wheat proteins are classified into gluten and non-gluten groups Osborne and Clapp (1907). Gliadnin provides viscosity and glutenin provides viscoelasticity properties to the dough Coulson and Sim (1965). By the absence of few allelic variants which as high molecular weight 
subunits of glutenin will affect the quality of the bread Wieser and Zimmermann (2000). Water and environmental factors will also influence the quality of the proteins. However, cultivators choose high glutenin content for increasing the strength of the dough Marchylo et al. (1992). Hence nitrogen content and fertilizers will increase the quality of the grain protein.

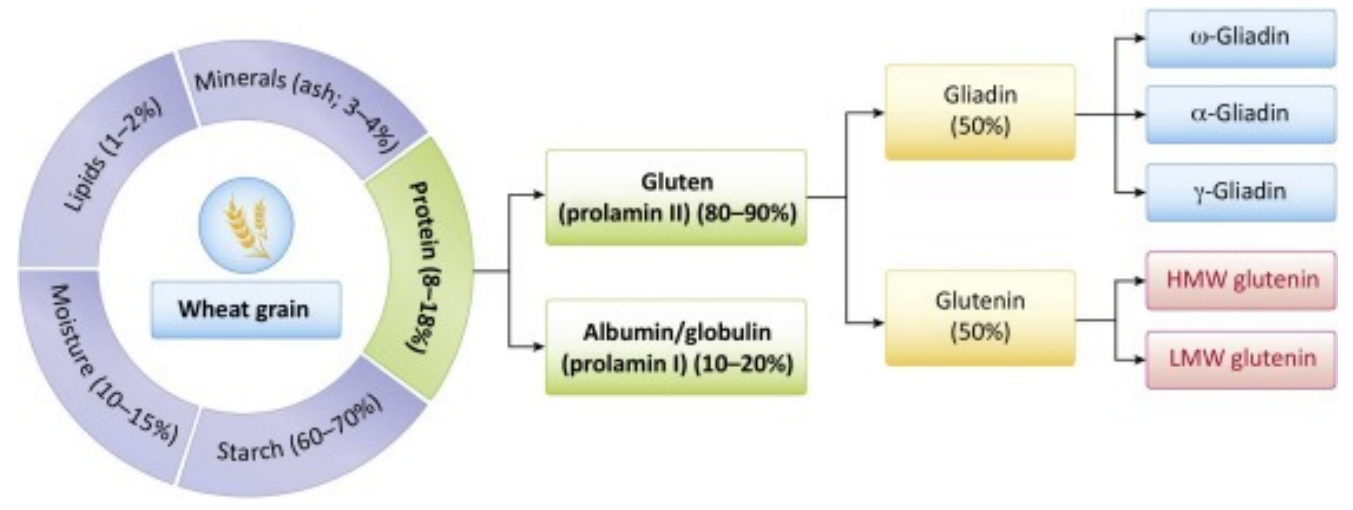

Trends in Plant Science

Figure 2 Functions of wheat grain Zörb et al. (2018)

\section{Functionality of protein in bakery products}

Main functional properties of protein are it provides viscoelasticity to the dough and are characterized by unusual amounts of residues of glutamine Belton (1993). They are important sources of plant protein which are related to conformational state and are affected by processing conditions. Certain properties such as colour, flavour formation, taste, and fat absorption capacities are obtained after baking process. Most of the protein is used in native form and small quantities are used in the form of concentrates, vital and non-vital wheat gluten isolates Ortolan and Steel (2017). The protein percentage in the wheat content ranges from $8 \%$ to $18 \%$ useful to make buns and bread for retaining gas and are helpful for rising of dough in the fermentation process and baking process Lane (1989). Cakes, biscuits, and cookies are generally made with low protein flour (8\% to 9\%) providing low water absorption, low damage to starch, good granulation of flour hence it is useful for making good biscuits Bailey (1914). Hence water absorption of the flour depends on the starch and protein content. So, the water content used to form dough should be minimum so flour of low water absorption will have low protein and less starch damage Heinis (2010). With the increase in the protein content of wheat grain there is a gradual increase of gluten content, hence several studies have suggested the non-gluten proteins will not play an important role in the making of bread Kim and Lee (2015). The differences in gliadnin and glutenin will change the extensibility and elasticity properties of dough. Recent studies have shown that by addition of total gliadin and its subgroups will increase the quality of the bread therefore increasing the volume of the loaf Shewry (2009). Glutenin is useful to provide firmness in making of bread as it can increase the stability through a three dimensions network which is formed when sulphur cross linkages are developed during kneading process Dhaka and Khatkar (2015). Gluten proteins are the storage proteins of wheat and are very unique as they are also functional proteins, they do not possess any enzyme activity but they are only proteins which possess strong and cohesive dough to retain gases and produce light baked goods Ortolan and Steel (2017). 
Molecular size distribution is an important functional property of the wheat flour Tegge (1985). Hence longer mixing of dough will increase the extensibility and improves the quality of the flour in bread making. A continuous gluten network will not be formed with the week flour due it is quality characteristic. Hence the week flour lacks strength and elasticity, but by the addition of good amount of sugar, fat, and less energy a greater number of biscuits can be prepared when the dough is exposed to high temperature with such properties Belton (1993). Hence the gliadin properties are very small and possess less interaction with the surface which makes it to act as a ball bearing action which is useful for extensibility and therefore desirable biscuits can be produced Brockway (1990).

Methods that are used to measure protein content in the food are kjeldahl method, dumas method, spectrophotometric methods, and physical methods. The concentration of protein is calculated by the amount of nitrogen content present in the food product. In the present Study dumas method is used for estimating nitrogen percentage in the wheat grain. It is calculated by thermal conductivity process. This method is faster compared to kjeldahl method. It does not use any harmful chemicals. Food samples are measured automatically in dumas method Fieldner and Taylor (1915).

\section{RESULT}

The result about the grain protein in the below Figure 3 data on the protein showed that there was a significant difference in the flour quality used for bread making process. The percentage of the nitrogen has also significantly affected the protein quality of the grain. Two nitrogen doses were supplied to the crop, evidently the protein percentage has increased gradually with increase of nitrogen to $350 \mathrm{~kg} / \mathrm{ha}$. The maximum protein was obtained highest supply of $350 \mathrm{~kg} / \mathrm{ha}$. The minimum protein was obtained at lowest supply of $100 \mathrm{~kg} / \mathrm{ha}$. The obtained results were agreed with the findings of Chaudhry and Mehmood (1998) who described that the protein content will be significantly affected by the nitrogen percentage. Bänziger et al. (1994) findings showed that that the genotypic variation in protein of grain may also affected by the supply of nitrogen in the soil. By the above results it can be concluded that bread grown with $350 \mathrm{~kg} / \mathrm{h}$ supply has high protein content in bread; protein rich and more yield can also be gained by application of proper amount of nitrogen.

The protein content of a bread sample that is grown in two different nitrogen supply was shown in the figure using IBM SPSS statistical analysis (SPSS survival manual: a step-by-step guide to data analysis using IBM SPSS, 2013). Hence, $p$ value is less than 0.05 , which is at $95 \%$ confidence level, we reject our null hypothesis. In other words, there is significant difference between the means of two groups 


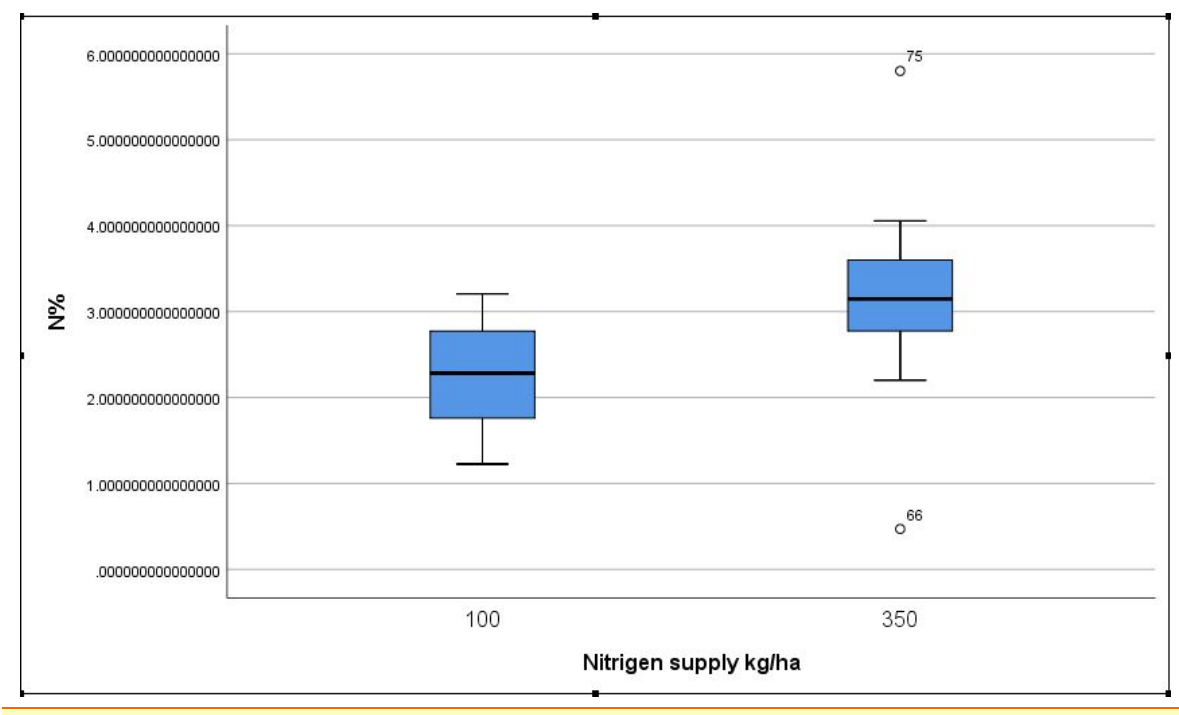

Figure 3 Comparison of a protein percentage in two different levels of nitrogen supply

The Smaller the standard error, the representative sample will be more. In our case the minimum standard error is 0.00485 which is of 1 st group i.e. In the case of $100 \%$

Group Statistics

\begin{tabular}{ll|c|c|c|c} 
& Nitrigen supply kg/ha & $N$ & Mean & Std. Deviation & $\begin{array}{c}\text { Std. Error } \\
\text { Mean }\end{array}$ \\
\hline Conversion factor & 100 & 49 & 13.32098638 & 3.398024609 & .4854320870 \\
\cline { 2 - 7 } & 350 & 49 & 18.45818549 & 4.403551621 & .6290788030 \\
\hline
\end{tabular}

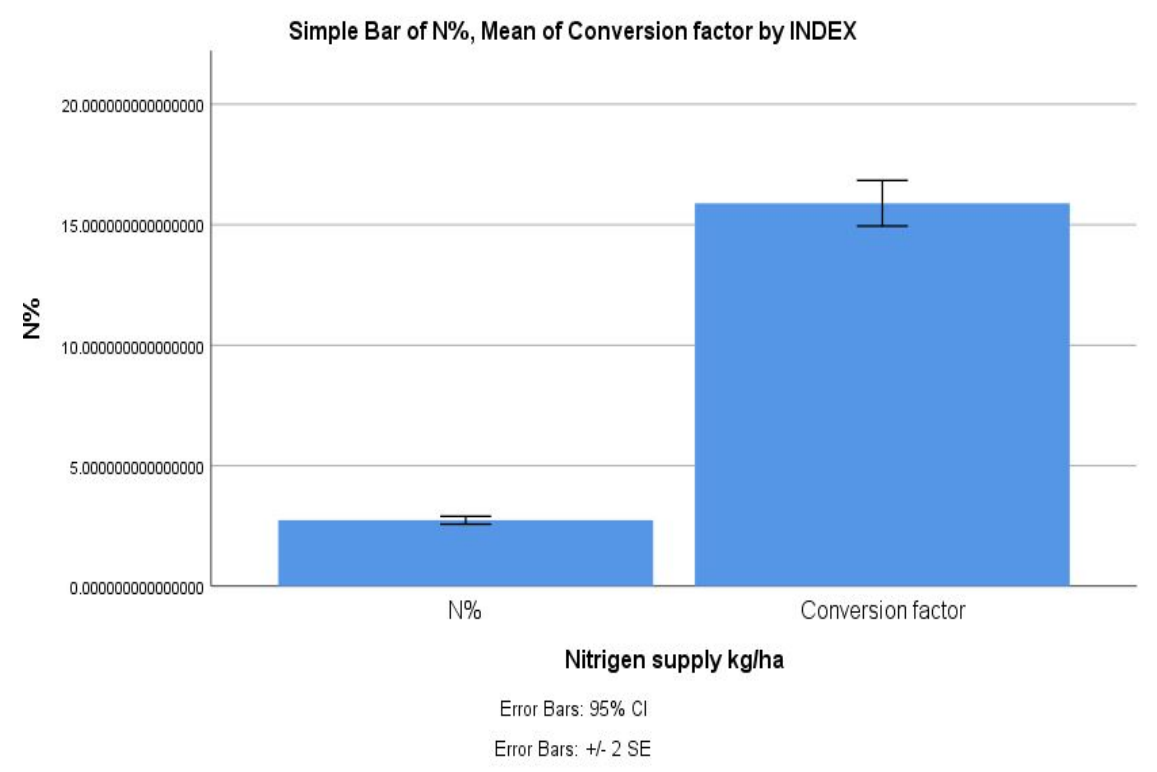

Figure 4 protein content of bread variety grown in two different levels of fertilizers; standard errors were displayed. 


\section{DISCUSSION}

In the present study we discussed about the effect of nitrogen supply to the protein content of the wheat grain and the results obtained showed high percentage of protein supplied with $350 \mathrm{~kg} / \mathrm{ha}$; three times more compared $100 \mathrm{~kg} / \mathrm{ha}$. The result may depend on several factors such as supply of nutrition and problems during milling. Hence the topics are covered here in this section including the similar works done by other researchers.

Quantity and quality of the protein are very important for the protein development in the wheat crop. To obtain high quality of protein, plant should contain high molecular weight, long chain gluten proteins Yu et al. (2017). As we discussed above (Figure 2), the gluten proteins such as albumin, globulin and gliadinin provides extensibility and processing properties to the dough. Nitrogen and sulphur are important and acts as a key nutrient for the growth of the grain protein. Nitrogen ensures the plant to grow with high protein percentage and time is also considered very important to attain good yield. Research, studies proved that effect of nutrients such as sulphur and nitrogen lead to changes in $1 \%$ grain protein for every50kg/ha Daniel and Triboi (2000). Temperature and nitrogen supply will affect the protein and gliadinin content. Proteins and gladinin in the flour will increase with increase of temperature where the quality of gliadnin per grain will negatively affected by temperature and fertilization of nitrogen Daniel and Triboi, (2000)

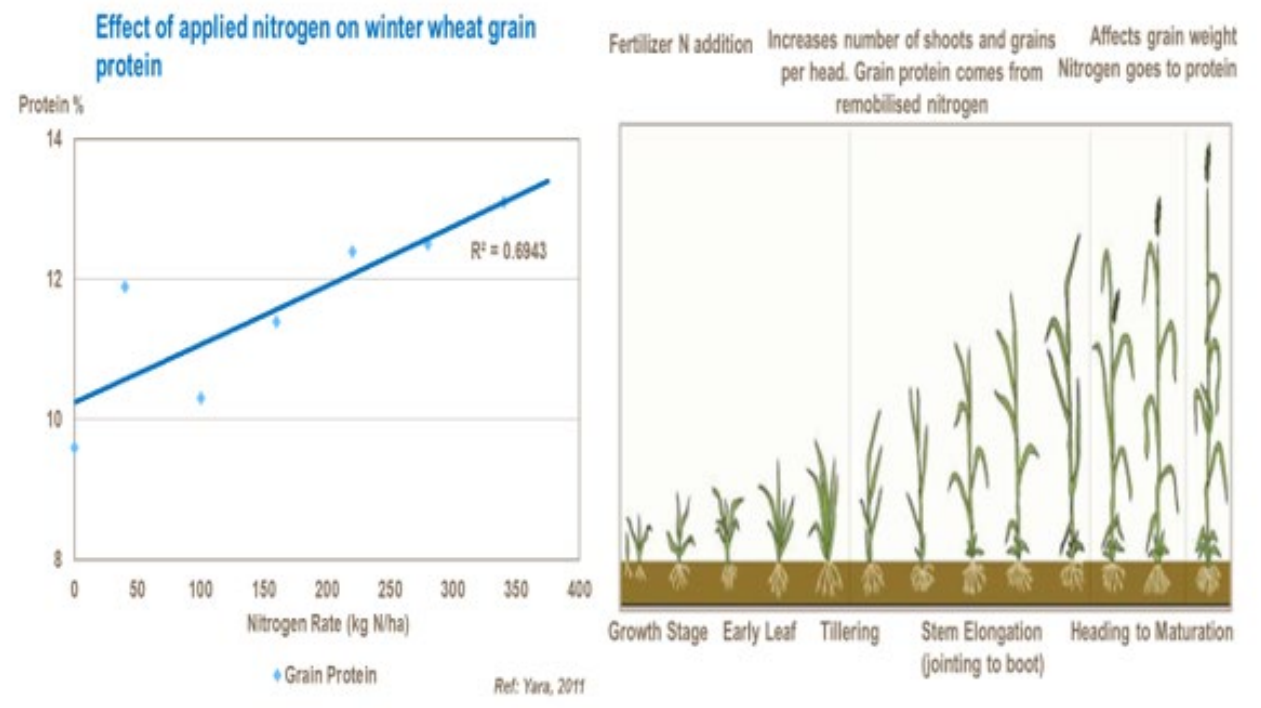

Figure 5 Depicts the research studies done on the effect of the nitrogen on wheat grain protein Makowski et al. (1999)

Grain protein with nitrogen in wheat should have $11 \%$, however in making of the bread the protein should be $12 \%$, with less amount of sulphur supply Ortolan and Steel (2017). The dough that is produced will get affected and amino acids such as methionine, cysteine and lysine will affect the baking properties. Micronutrients such as zinc and manganese will influence the metabolism rate of nitrogen. However, increased metabolism increases the nitrogen content in the developing proteins. 
On the other hand, the milling process is a crucial stage affecting the concentration of the protein and nutrients in by products of the wheat grain. Aleurone layer and germ of wheat kernel is important and are rich in minerals and proteins. Conventional milling method will reduce the nutritional value of the wheat flour and concentrates the minerals in the milling residues Cubadda et al. (2009). White flour with $68 \%$ of mineral extraction means $32 \%$ of grain is not present in the wheat flour. Milling of wheat not only decreases the nutritional value but compared to the other flour it has high amount of nutrients even after the milling process. Nutritional value and antioxidant value will depend on the type of the soil, temperature and other climatic conditions Adom et al. (2003). According to Cooper, and Blakeney (1990) there was a significant difference identified between hard and soft wheat flours showing low protein percentage before and after milling process. Protein content is found to be $14.40 \%$ for hard wheat and soft wheat is $9.11 \%$ respectively. According to Butt et al. (2004) depending on the proportion of the bran the protein content will be increased showed in his experiment studies done on $20 \%$ and $25 \%$ bran supplements on bread making.

Bread making process is very important including three stages such as mixing, fermentation and baking process. Farinograph is used to identify the nature of the dough. Extensiograph is used to identify the extensibility which is used for gas retention during fermentation process. Fermentograph used to identify the volume of the loaf during fermentation process Daniels and Fisher (1976). The success of the tests directly depends on the floor behaviour in the mill and bakery. Protein changes and starch changes during baking can be observed due to variety of composition Janssen et al. (1996). Research studies suggested that ash content and dough time has increased after milling to $1.95 \%$ and 6 minutes respectively Hrušková et al. (2006). Research studies proved that the higher the resistance test the bread volume will be high and suitable for baking process Cubadda et al. (2009). Wheat protein content, fermentation gases, absorption of water has an important relationship between milling process and baking quality. Affectivity of milling will be based on parameter such as ash content and hardness which have influence on wheat flour during baking process. Fermentation is related to the content of the protein and the quality will changes the nature of the dough during proofing process (Purlis, 2012). Others studies have proven that Czech varieties have good behaviour at proofing and maturation resulting in good volume of bread shapes during baking process Hrušková et al. (2006).

Proper input of nitrogen is also very important for the crops to yield high protein content and good economic benefit. Some farmers due to lack of knowledge applies more nitrogen (180kg h-1 y-1) which causes environmental problems Vitousek et al. (1997). Major problems include soil and water acidification, contamination of ground and surface water, increase of depletion of ozone layer and injury of the crops. Due to nitrogen emission green-house gases will be increased, loss of biodiversity and production of airborne substances have been observed Galloway et al. (2002).

The movement of nitrogen in the soil system and plant till the final percentage of plant harvest was clearly shown in below (Figure 6) 


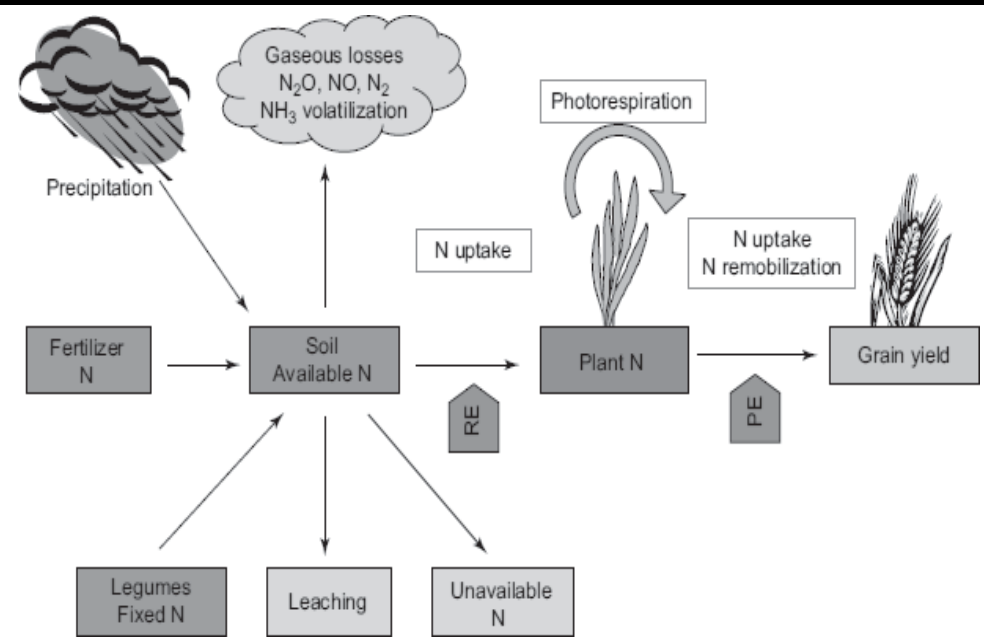

Figure 6 Presence of nitrogen in plants and environment Good et al. (2004)

In future water scarcity can also be seen. The cost of fertilizers will be increased. Variation in genetics will be observed in the plants. Increasing nitrogen content will increase the efficiency in drought conditions and leaching of soil Foulkes et al. (2009). Studies suggest that pollution can be caused in ground water, euterification of lakes and rivers, production of nitrogen oxides and denitrification of soil bacteria is observed Chaves et al. (2003). Therefore, nitrogen accumulation into the soil has increased the attention. At present the nitrogen use efficiency is low because the nitrogen fertilizer will greatly surpass the needs of the crop Ju et al. (2009). Hence the needs of the crop are related to ammonium levels in the soil. Therefore, the protein content will be increased with increase in nitrogen content. Studies suggested different nitrogen application rates on plants will apparently affect the chlorophyll and photosynthetic activity of flag leaves Dahal et al. (2014). Good nitrogen content will increase the root traits to increase the length of root density. Reduced grain nitrogen may increase NUE in wheat grain for making bread cultivars, more NUE will be linked to high nitrogen assimilation Foulkes et al. (2009).

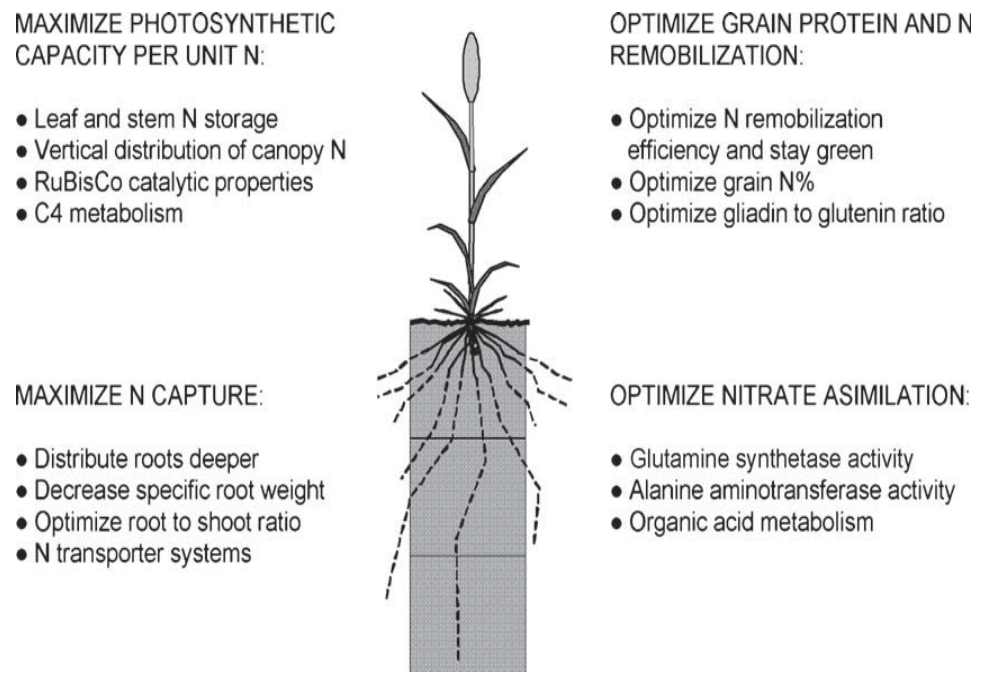

Figure 7 Management strategies for high nitrogen use efficiency Foulkes et al. (2009) 


\section{CONCLUSION}

Wheat is an important crop consumed all over the world due to its nutritional properties. Wheat grain contains important proteins such as gliadnin and gluteinin which are responsible for baking properties. Gliadinin and glutenin will together provide certain functions helpful to form dough. Hence factors' effecting the growth of crop is also important for the increase of protein in the dough. Several factors such as time, temperature, amount of fertilizer, milling process can affect the protein content. Therefore, nitrogen plays an important role in the growth of protein in the wheat grain. High input of nitrogen can lead to environmental pollution thus leading to damage of ecosystem. Hence proper nitrogen input is necessary for the wheat crop. The concentration of the nitrogen with different percentage will yields different results as we discussed above. The baking quality of the wheat flour is determined by the amount of protein present in the product. In other words, future for bakery products depends on the nitrogen input, nitrogen assimilation to the crop as it increases the protein content and further nutritional value of the product

\section{ACKNOWLEDGMENT}

I take pride to thank my professor Dr. Jibin He who encouraged me to work better in Teesside University. I wish to thank my parents and brother for their love and encouragement throughout my career.

\section{REFERENCES}

Adom, K., Sorrells, M. And Liu, R., (2003). Phytochemical Profiles And Antioxidant Activity Of Wheat Varieties. Journal Of Agricultural And Food Chemistry, 51(26), Pp.7825-7834. Retrieved From Https://Doi.Org/10.1021/Jf0304041

Australian And New Zealand Journal Of Public Health, (2013). SPSS Survival Manual: A Step By Step Guide To Data Analysis Using IBM SPSS. 37(6), Pp.597-598. Retrieved From Https://Doi.Org/10.1111/1753-6405.12166

Barneix, A. And Guitman, M., (1993). Leaf Regulation Of The Nitrogen Concentration In The Grain Of Wheat Plants. Journal Of Experimental Botany, 44(10), Pp.1607-1612. Retrieved From Https://Doi.Org/10.1093/Jxb/44.10.1607

Burgess, S. And Shewry, P., (1986). Identification Of Homologous Globulins From Embryos Of Wheat, Barley, Rye And Oats. Journal Of Experimental Botany, 37(12), Pp.1863-1871. Retrieved From Https://Doi.Org/10.1093/Jxb/37.12.1863

Bailey, C., (1914). The Composition And Quality Of Mexican Wheats And Wheat Flours. Agronomy Journal, 6(2), Pp.57-64. Retrieved From Https://Doi.Org/10.2134/Agronj1914.00021962000600020002x

Belton, P., (1993). Biochemistry Of Food Proteins. Trends In Food Science \& Technology, 4(7), Pp.232-233. Retrieved From Https://Doi.Org/10.1016/0924-2244(93)90160-C

Bogard, M., Allard, V., Brancourt-Hulmel, M., Heumez, E., Machet, J., Jeuffroy, M., Gate, P., Martre, P. And Le Gouis, J., (2010). Deviation From The Grain Protein Concentration-Grain Yield Negative Relationship Is Highly Correlated To Post-Anthesis N Uptake In Winter Wheat. Journal Of Experimental Botany, 


$\begin{array}{lccc}\text { 61(15), } & \text { Pp.4303-4312. } & \text { Retrieved } & \text { From } \\ \text { Https://Doi.Org/10.1093/Jxb/Erq238 } & & \end{array}$

Brennan, C., (2009). Baked Products Science, Technology And Practice. International Journal Of Food Science \& Technology, 44(3), Pp.656-656. Retrieved From Https://Doi.Org/10.1111/J.1365-2621.2007.01655.X

Brockway, B., (1990). Modern Cereal Science And Technology. Food Chemistry, 37(1), P.79. Retrieved From Https://Doi.Org/10.1016/03088146(90)90049-A

Butt, M., Ihsanullah Qamar, M., Anjum, F., Aziz, A. And Atif Randhawa, M., (2004). Development Of Minerals-Enriched Brown Flour By Utilizing Wheat Milling By-Products. Nutrition \& Food Science, 34(4), Pp.161-165. Retrieved From Https://Doi.Org/10.1108/00346650410544855

Bänziger, M., Feil, B. And Stamp, P., (1994). Competition Between Nitrogen Accumulation And Grain Growth For Carbohydrates During Grain Filling Of Wheat. Crop Science, 34(2), Pp.440-446. Retrieved From Https://Doi.Org/10.2135/Cropsci1994.0011183X003400020025x

Coulson, C. And Sim, A., (1965). Proteins Of Wheat Flour. Nature, 208(5010), Pp.583584. Retrieved From Https://Doi.Org/10.1038/208583a0

Chaves, M., Maroco, J. And Pereira, J., (2003). Understanding Plant Responses To Drought - From Genes To The Whole Plant. Functional Plant Biology, 30(3), P.239. Retrieved From Https://Doi.Org/10.1071/FP02076

Cooper, J. And Blakeney, A., (1990). The Effect Of Two Forms Of Nitrogen Fertiliser Applied Near Anthesis On The Grain Quality Of Irrigated Wheat. Australian Journal Of Experimental Agriculture, 30(5), P.615. Retrieved From Https://Doi.Org/10.1071/EA9900615

Cubadda, F., Aureli, F., Raggi, A. And Carcea, M., (2009). Effect Of Milling, Pasta Making And Cooking On Minerals In Durum Wheat. Journal Of Cereal Science, 49(1), Pp.92-97. Retrieved From Https://Doi.Org/10.1016/J.Jcs.2008.07.008

Dahal, K., Knowles, V., Plaxton, W. And Hüner, N., (2014). Enhancement of Photosynthetic Performance, Water Use Efficiency And Grain Yield During Long-Term Growth Under Elevated CO2 In Wheat And Rye Is Growth Temperature And Cultivar Dependent. Environmental And Experimental Botany, 106, Pp.207-220. Retrieved From Https://Doi.Org/10.1016/J.Envexpbot.2013.11.015

Daniel, C. And Triboi, E., (2000). Effects Of Temperature And Nitrogen Nutrition On The Grain Composition Of Winter Wheat: Effects On Gliadin Content And Composition. Journal Of Cereal Science, 32(1), Pp.45-56. Retrieved From Https://Doi.Org/10.1006/Jcrs.2000.0313

Daniels, D. And Fisher, N., (1976). Release Of Carbon Dioxide From Dough During Baking. Journal Of The Science Of Food And Agriculture, 27(4), Pp.351-357. Retrieved From Https://Doi.Org/10.1002/Jsfa.2740270409

Dhaka, V. And Khatkar, B., (2015). Effects Of Gliadin/Glutenin And HMW-GS/LMWGS Ratio On Dough Rheological Properties And Bread-Making Potential Of Wheat Varieties. Journal Of Food Quality, 38(2), Pp.71-82. Retrieved From Https://Doi.Org/10.1111/Jfq.12122

Fieldner, A. And Taylor, C., (1915). A Comparison Of Various Modifications Of The Kjeldahl Method With The Dumas Method Of Determining Nitrogen In Coal, 
With Notes On Errors In The Dumas Method Due To Nitrogen Evolved From The Copper Oxide. Journal Of Industrial \& Engineering Chemistry, 7(2), Pp.106-112. Retrieved From Https://Doi.Org/10.1021/Ie50074a006

Foulkes, M., Hawkesford, M., Barraclough, P., Holdsworth, M., Kerr, S., Kightley, S. And Shewry, P., (2009). Identifying Traits To Improve The Nitrogen Economy Of Wheat: Recent Advances And Future Prospects. Field Crops Research, 114(3), Pp.329-342. Retrieved From Https://Doi.Org/10.1016/J.Fcr.2009.09.005

Galloway, J., Cowling, E. And Kessler, E., (2002). Reactive Nitrogen. AMBIO: A Journal Of The Human Environment, 31(2), Pp.59-59. Retrieved From Https://Doi.Org/10.1579/0044-7447-31.2.59

Good, A., Shrawat, A. And Muench, D., (2004). Can Less Yield More? Is Reducing Nutrient Input Into The Environment Compatible With Maintaining Crop Production?. Trends In Plant Science, 9(12), Pp.597-605. Retrieved From Https://Doi.Org/10.1016/J.Tplants.2004.10.008

Heinis, J., (2010). Review Ofprinciples Of Cereal Science And Technology, 3rd Ed. Journal Of Agricultural \& Food Information, 11(3), Pp.256-257. Retrieved From Https://Doi.Org/10.1080/10496505.2010.494137

Hellemans, T., Landschoot, S., Dewitte, K., Van Bockstaele, F., Vermeir, P., Eeckhout, M. And Haesaert, G., (2018). Impact Of Crop Husbandry Practices And Environmental Conditions On Wheat Composition And Quality: A Review. Journal of Agricultural And Food Chemistry, 66(11), Pp.2491-2509. Retrieved From Https://Doi.Org/10.1021/Acs.Jafc.7b05450

Hrušková, M., Švec, I. And Jirsa, O., (2006). Correlation Between Milling And Baking Parameters Of Wheat Varieties. Journal Of Food Engineering, 77(3), Pp.439444. Retrieved From Https://Doi.Org/10.1016/J.Jfoodeng.2005.07.011

Janssen, A., Van Vliet, T. And Vereijken, J., (1996). Fundamental And Empirical Rheological Behaviour Of Wheat Flour Doughs And Comparison With Bread Making Performance. Journal Of Cereal Science, 23(1), Pp.43-54. Retrieved From Https://Doi.Org/10.1006/Jcrs.1996.0004

Johansson, J., Isacsson, U. And Glimelius, B., (2001). In Regard To Zurlo Et Al. IJROBP 2000;48:277-288. International Journal of Radiation Oncology*Biology*Physics, $\quad 50(1), \quad$ Pp.279-280. Retrieved From Https://Doi.Org/10.1016/S0360-3016(01)01457-2

Ju, X., Xing, G., Chen, X., Zhang, S., Zhang, L., Liu, X., Cui, Z., Yin, B., Christie, P., Zhu, Z. And Zhang, F., (2009). Reducing Environmental Risk By Improving N Management In Intensive Chinese Agricultural Systems. Proceedings Of The National Academy Of Sciences, 106(9), Pp.3041-3046. Retrieved From Https://Doi.Org/10.1073/Pnas.0813417106

Kim, W. And Lee, G., (2015). Comparison Of Imported Wheat Flour Bread Making Properties And Korean Wheat Flour Bread Making Properties Made By Various Bread Making Methods. Journal Of The Korean Society Of Food Science And Nutrition, 44(3), Pp.434-441. Retrieved From Https://Doi.Org/10.3746/Jkfn.2015.44.3.434

Laidig, F., Piepho, H., Rentel, D., Drobek, T., Meyer, U. And Huesken, A., (2016). Breeding Progress, Environmental Variation And Correlation Of Winter Wheat Yield And Quality Traits In German Official Variety Trials And OnFarm During 1983-2014. Theoretical And Applied Genetics, 130(1), Pp.223245. Retrieved From Https://Doi.Org/10.1007/S00122-016-2810-3 
Lane, R., (1989). Cereal And Cereal Products. Journal Of AOAC INTERNATIONAL, 72(1), Pp.85-85. Retrieved From Https://Doi.Org/10.1093/Jaoac/72.1.85a

Munier-Jolain, N. And Salon, C., (2005). Are The Carbon Costs Of Seed Production Related To The Quantitative And Qualitative Performance? An Appraisal For Legumes And Other Crops. Plant, Cell And Environment, 28(11), Pp.13881395. Retrieved From Https://Doi.Org/10.1111/J.13653040.2005.01371.X

Makowski, D., Wallach, D. And Meynard, J., (1999). Models Of Yield, Grain Protein, And Residual Mineral Nitrogen Responses To Applied Nitrogen For Winter Wheat. Agronomy Journal, 91(3), Pp.377-385. Retrieved From Https://Doi.Org/10.2134/Agronj1999.00021962009100030005x

Marchylo, B., Lukow, O. And Kruger, J., (1992). Quantitative Variation In High Molecular Weight Glutenin Subunit 7 In Some Canadian Wheats. Journal Of Cereal Science, 15(1), Pp.29-37. Retrieved From Https://Doi.Org/10.1016/S0733-5210(09)80054-4

Neumann, S., Fuchs, A., Mulkidjanian, A. And Frishman, D., (2010). Current Status Of Membrane Protein Structure Classification. Proteins: Structure, Function, And Bioinformatics, 78(7), Pp.1760-1773. Retrieved From Https://Doi.Org/10.1002/Prot.22692

Ortolan, F. And Steel, C., (2017). Protein Characteristics That Affect The Quality Of Vital Wheat Gluten To Be Used In Baking: A Review. Comprehensive Reviews In Food Science And Food Safety, 16(3), Pp.369-381. Retrieved From Https://Doi.Org/10.1111/1541-4337.12259

Osborne, T. And Clapp, S., (1907). A NEW DECOMPOSITION PRODUCT OF GLIADIN. American Journal of Physiology-Legacy Content, 18(2), Pp.123-128. Retrieved From Https://Doi.Org/10.1152/Ajplegacy.1907.18.2.123

Pechanek, U., Karger, A., Gröger, S., Charvat, B., Schöggl, G. And Lelley, T., (1997). Effect Of Nitrogen Fertilization On Quantity Of Flour Protein Components, Dough Properties, And Breadmaking Quality Of Wheat. Cereal Chemistry Journal, 74(6), Pp.800-805.Purlis, E., 2012. Baking Process Design Based On Modelling And Simulation: Towards Optimization Of Bread Baking. Food Control, 27(1), Pp.45-52. Retrieved From Https://Doi.Org/10.1094/CCHEM.1997.74.6.800

Schulz, R., Makary, T., Hubert, S., Hartung, K., Gruber, S., Donath, S., Döhler, J., Weiß, K., Ehrhart, E., Claupein, W., Piepho, H., Pekrun, C. And Müller, T., (2015). Is It Necessary To Split Nitrogen Fertilization For Winter Wheat? On-Farm Research On Luvisols In South-West Germany - CORRIGENDUM. The Journal Of Agricultural Science, 153(7), Pp.1149-1149. Retrieved From Https://Doi.Org/10.1017/S0021859615000684

Seilmeier, W., Belitz, H. And Wieser, H., (1991). Separation And Quantitative Determination of High-Molecular-Weight Subunits of Glutenin From Different Wheat Varieties And Genetic Variants of The Variety Sicco. Zeitschrift FoR Lebensmittel-Untersuchung Und -Forschung, 192(2), Pp.124-129. Retrieved From Https://Doi.Org/10.1007/BF01202625

Shewry, P., (2009). Wheat. Journal Of Experimental Botany, 60(6), Pp.1537-1553. Retrieved From Https://Doi.Org/10.1093/Jxb/Erp058

Singh, N., Kaur, N., Katyal, M., Kaur, A. And Shevkani, K., (2016). Characteristics Of Starch Separated From Coarse And Fine Flour Fractions Obtained From 
Hard, Medium-Hard, And Soft Indian Wheat Cultivars. Starch - Stärke, 69(12), P.1600012. Retrieved From Https://Doi.Org/10.1002/Star.201600012

Tegge, G., (1985). Vetter, J. L. (Edit.): Dairy Products For The Cereal Processing Industry (Molkereiprodukte Für Die Getreideverarbeitende Industrie). American Association Of Cereal Chemistry, St. Paul, MN (USA) 1984. 208 P., Softcover \$18.00 AACC Members, \$23.00 Nonmembers. Starch - Stärke, 37(5), Pp.177-177. Retrieved Https://Doi.Org/10.1002/Star.19850370519

Tegge, G., (1987). Hoseney, R. C.: Principles Of Cereal Science And Technology. Published By The American Association Of Cereal Chemists, Inc., St. Paul, Minnesota (USA) 1986. 327 Pages, With Numerous Pictures, Diagrams And Tables. ISBN 0-913250-43-0, Hardcover, List Price \$ 49,95. AACC Member Price \$ 39,95. Starch - Stärke, 39(4), Pp.145-145. Retrieved From Https://Doi.Org/10.1002/Star.19870390416

Ullah Chaudhry, A. And Mehmood, R., (1998). Determination Of Optimum Level of Fertilizer Nitrogen For Varrieties Of Wheat (Triticum Aestivum L.). Pakistan Journal of Biological Sciences, 1(4), Pp.351-353. Retrieved From Https://Doi.Org/10.3923/Pjbs.1998.351.353

Vitousek, P., Aber, J., Howarth, R., Likens, G., Matson, P., Schindler, D., Schlesinger, W. And Tilman, D., (1997). HUMAN ALTERATION OF THE GLOBAL NITROGEN CYCLE: SOURCES AND CONSEQUENCES. Ecological Applications, 7(3), Pp.737-750. Retrieved From Https://Doi.Org/10.1890/10510761(1997)007[0737:HAOTGN]2.0.CO;2

Wan, Y., Poole, R., Huttly, A., Toscano-Underwood, C., Feeney, K., Welham, S., Gooding, M., Mills, C., Edwards, K., Shewry, P. And Mitchell, R., (2008). Transcriptome Analysis Of Grain Development In Hexaploid Wheat. BMC Genomics, 9(1), P.121. Retrieved From Https://Doi.Org/10.1186/14712164-9-121

Wieser, H. And Zimmermann, G., (2000). Importance Of Amounts And Proportions Of High Molecular Weight Subunits Of Glutenin For Wheat Quality. European Food Research And Technology, 210(5), Pp.324-330. Retrieved From Https://Doi.Org/10.1007/S002170050558

Yu, X., Chen, X., Wang, L., Yang, Y., Zhu, X., Shao, S., Cui, W. And Xiong, F., (2017). Novel Insights Into The Effect Of Nitrogen On Storage Protein Biosynthesis And Protein Body Development In Wheat Caryopsis. Journal Of Experimental Botany, 68(9), Pp.2259-2274. Retrieved From Https://Doi.Org/10.1093/Jxb/Erx108

Zadoks, J., Chang, T. And Konzak, C., (1974). A Decimal Code For The Growth Stages Of Cereals. Weed Research, 14(6), Pp.415-421. Retrieved From Https://Doi.Org/10.1111/J.1365-3180.1974.Tb01084.X

Zörb, C., Langenkämper, G., Betsche, T., Niehaus, K. And Barsch, A., (2006). Metabolite Profiling Of Wheat Grains (Triticum Aestivuml.) From Organic And Conventional Agriculture. Journal Of Agricultural And Food Chemistry, 54(21), Pp.8301-8306. Retrieved From Https://Doi.Org/10.1021/Jf0615451

Zörb, C., Ludewig, U. And Hawkesford, M., (2018) . Perspective On Wheat Yield And Quality With Reduced Nitrogen Supply. Trends In Plant Science, 23(11), Pp.1029-1037. 


\section{APPENDIX}

\begin{tabular}{|c|c|c|c|c|c|c|c|c|c|c|}
\hline & & $\begin{array}{l}\text { Lemenes Tesst } \\
\text { Valiad }\end{array}$ & & & & & Hestion Evality & allleans & & \\
\hline & & & & & & & Mean & Sot ETror & $\begin{array}{l}\text { 958 corifidence } \\
\text { Ditere }\end{array}$ & enthena dithe \\
\hline & & f & Sig. & 1 & $\|$ & 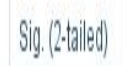 & Diflerence & DHerence & Lover & Unper \\
\hline Convesison fator & $\begin{array}{l}\text { Evalualariances } \\
\text { assumed }\end{array}$ & .264 & .009 & .0 .465 & 96 & .000 & .5.13799912. & .7969590372 & .67144617 & .3559959640 \\
\hline & $\begin{array}{l}\text { Exul wainares not } \\
\text { assuned }\end{array}$ & & & .0 .465 & 90.201 & .000 & .5.13799912. & .7969907037. & .0771565699 & .355804126 \\
\hline
\end{tabular}

\section{APPENDIX- A}

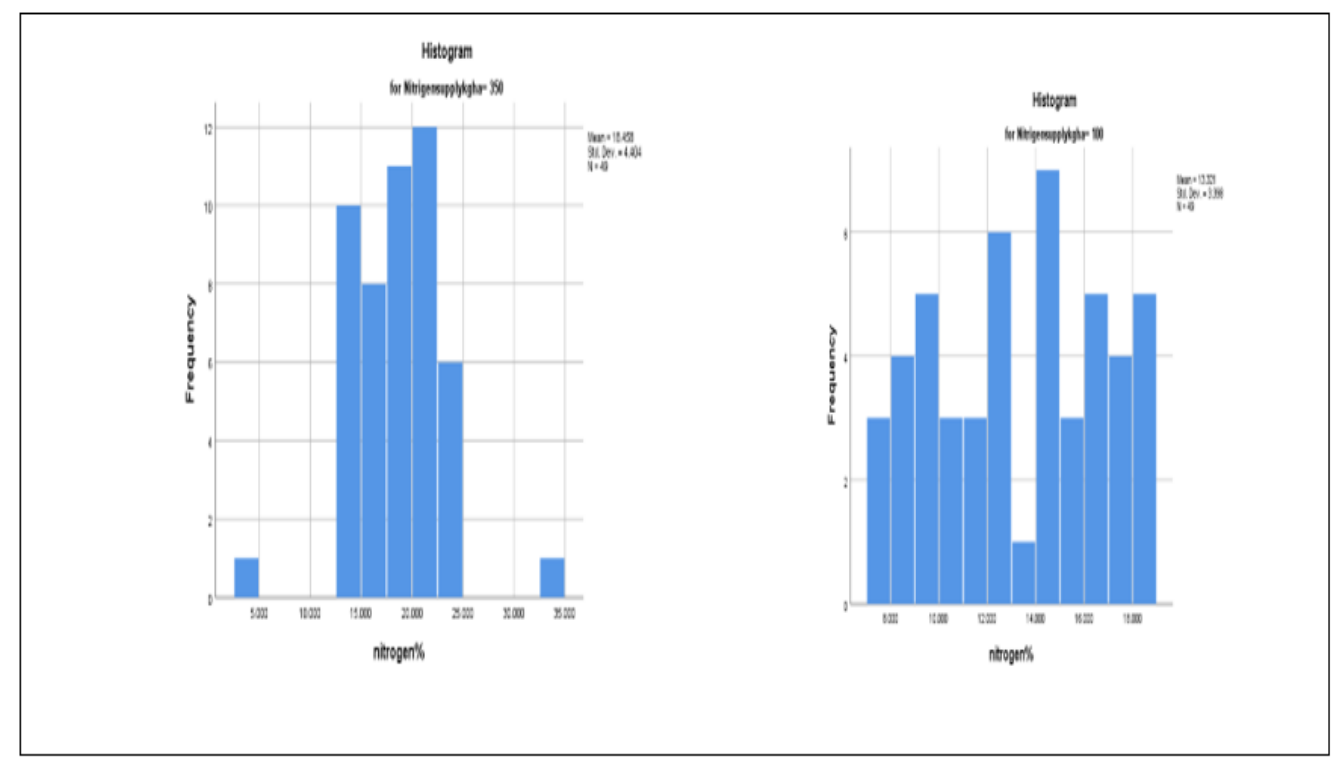

APPENDIX - B 


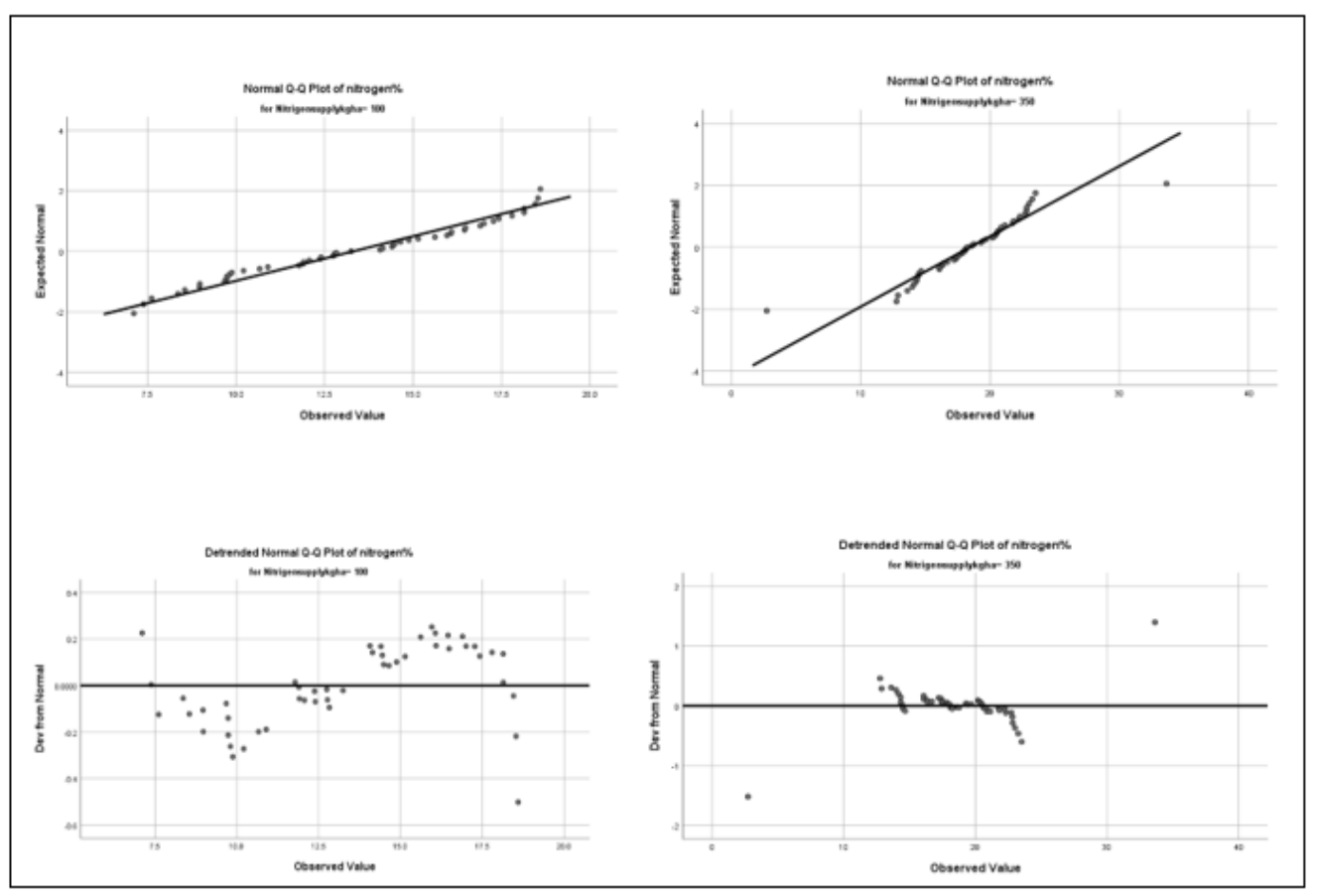

APPENDIX - C 